\title{
Immersion time in toxic solution for vigor evaluation of bean seeds ${ }^{1}$
}

\author{
Valquíria Aparecida Mendes de Jesus ${ }^{2 *}$, Alisson Vinicius de Araujo², \\ Paola Andrea Hormaza Martínez ${ }^{2}$, Eveline Mantovani Alvarenga², \\ Denise Cunha Fernandes dos Santos Dias ${ }^{2}$
}

\begin{abstract}
Considering the lack of information about the optimal permanence time of bean seeds in toxic solutions, this work aimed to evaluate the effect of different immersion times to differ of the seeds vigor. It was used five seed lots of cultivar 'Carnaval MG'. The seeds were immersed in a solution of ammonium chloride (1\%) during 15, 30, 45, 60 and 75 minutes, in BOD at $40{ }^{\circ} \mathrm{C}$. Then, the seeds were washed and placed to germinate. Additionally, germination tests, first count, emergence speed index (SEI), seedling emergence, fresh and dry weight of seedlings were carried out. A completely randomized design and a factorial scheme 5 x 5 (seed lots and immersion times) with four replications were employed. Analysis of variance and regression were performed and the means were compared by Tukey's test $(\alpha=5 \%)$. Pearson correlation was performed among treatments in toxic solution and the other tests. It was verified that it is possible to estimate the seed vigor, from different lots of beans using the immersion of seeds in a toxic solution of ammonium chloride (1\%) during 30 minutes.
\end{abstract}

Index terms: germination, $\mathrm{NH}_{4} \mathrm{Cl}$, Phaseolus vulgaris.

\section{Tempo de imersão em solução tóxica na avaliação do vigor de sementes de feijão}

\begin{abstract}
RESUMO - Devido à escassez de informações sobre o período ideal de permanência das sementes de feijão em soluções tóxicas, objetivou-se identificar qual o melhor tempo de imersão das sementes de Phaseolus vulgaris em cloreto de amônio para identificação do vigor de diferentes lotes. Utilizaram-se cinco lotes de sementes da cultivar 'Carnaval MG', as quais foram imersas em solução de cloreto de amônio $(1 \%)$ por $15,30,45,60$ e 75 minutos, e mantidas em BOD a $40^{\circ} \mathrm{C}$. Em seguida, foram lavadas e colocadas para germinar. Foram realizados testes de germinação, primeira contagem, IVE, emergência de plântulas, massa da matéria fresca e seca de plântulas. O delineamento foi inteiramente casualizado, no esquema fatorial 5 x 5 (lotes de feijão x tempos de imersão), com quatro repetições. Os dados foram submetidos à análise de variância e de regressão, sendo as médias comparadas pelo teste Tukey $(\alpha=5 \%)$. Foi realizada a correlação de Pearson entre os tratamentos referentes à solução tóxica e os demais testes. Verificou-se que é possível estimar o vigor de diferentes lotes de sementes de feijão quando se realiza a imersão das sementes em solução tóxica de cloreto de amônio a 1\% durante 30 minutos.
\end{abstract}

Termos para indexação: germinação, $\mathrm{NH}_{4} \mathrm{Cl}$, Phaseolus vulgaris.

\section{Introduction}

The production of quality bean seeds is especially important to ensure crop establishment. By the germination test it is possible to assess the ability of the seeds to produce normal seedlings under ideal conditions. However, the germination test does not always reveal performance differences between lots of seeds during storage or in the field (Bhering et al., 2003; Rix et al., 2011). The fainter degenerative changes non detected by the germination test greatly influence the performance potential of the seeds with reflections in storage capacity, field emergence, growth and yield of plants (KhajehHosseini and Rezazadeh, 2011). In modern agriculture, for a complete and efficient seed lot analysis, in terms of predicting

${ }^{1}$ Submitted on 03/01/2012. Accepted for publication on 09/24/2012.

${ }^{2}$ Departamento de Fitotecnia, Universidade Federal de Viçosa, 36570-000 - Viçosa, MG, Brasil.

*Corresponding author:<valquiria.jesus@ufv.br> 
how successful it will establish a vigorous population of seedlings under a broad environmental condition in the field, it is necessary to supplement the information provided by the germination test using vigor tests (Kikuti and Marcos-Filho, 2012). Information about the vigor also helps seed producers and farmers to better know the product they sell or purchase.

An ideal vigor test, in addition to being quick and easy to perform, must not require complex equipment and should also be applicable to efficiently determine the seed vigor to detect both small and large differences among seed lots. Various methods have been studied for the evaluation of seed vigor; however, studies related to the immersion in toxic solutions test are scarce. Boaro et al. (1984) verified the efficiency of this test to assess the vigor of bean seeds compared to the germination, accelerated aging and low temperature tests. Other studies have also demonstrated that the immersion in toxic solution test can be used to assess the level of vigor of maize (Borges et al., 1987) and sorghum seeds (Andrade et al., 1993). Howerver, other authors, such as Cardoso Sobrinho et al. (1998), Silva et al. (2001) and Soares et al. (2010) found that in sorghum the use of this test has not allowed the classification of the seed lots in vigor levels.

In the literature, there is controversy as to the applicability of the toxic solution test for assessing seed vigor, and there is not a standardized immersion time in the solution for this analysis. The toxic solution test is an auxiliary methodology whose use appears very promising vigor test. This test evaluates the germination of the seeds after a certain time of immersion in a toxic solution such as ammonium chloride $\left(\mathrm{NH}_{4} \mathrm{Cl}\right)$. More deteriorated seeds, which present higher permeability of the cell membranes, absorb more quickly the toxic solution, which results in lower germination.

Given the above, this study aimed to identify the best time of immersion of the bean seeds in ammonium chloride to identify the vigor of the different lots.

\section{Materials and Methods}

The experiment was conducted in the Department of Plant Science of Universidade Federal de Viçosa, Viçosa, Minas Gerais. Five lots of bean seeds, cultivar Carnaval MG (brindle type seeds) were used, which received the designation of L1, L2, L3, L4 and L5. For the characterization of the lots were performed the following tests:

Water content: performed by the oven method at $105 \pm 3{ }^{\circ} \mathrm{C}$, during 24 hours (Brasil, 2009).

Germination: it was used paper towel as substrate in the form of a roll, according to Brasil (2009). The test was conducted in a Mangelsdorf type germination chamber at $25{ }^{\circ} \mathrm{C}$, with four replicates of 50 seeds for each lot, and the results were presented as a mean percentage of normal seedlings obtained at 8 days after sowing.

First count: it was performed together with the germination test and consisted of the record of the percentage of normal seedlings obtained on the fourth day after sowing. Results were expressed as mean percentage of normal seedlings.

Immersion in toxic solution: the methodology described by Marcos-Filho et al. (1987) was followed, with modifications. Four replications of 50 seeds were immersed in a solution of ammonium chloride $\left(\mathrm{NH}_{4} \mathrm{Cl}\right)$ at a concentration of $1 \%$ for different times $(15,30,45,60$ and 75 minutes), incubated in BOD at $40{ }^{\circ} \mathrm{C}$. After each soaking period, the seeds were washed in running water for a minute to remove the excess solution. The seeds were then germinated and evaluated as described above for the germination test (Brasil, 2009).

Seedlings emergence: conducted in a greenhouse, whose minimum air temperature was $12{ }^{\circ} \mathrm{C}$, maximum $42{ }^{\circ} \mathrm{C}$ and means of $25.7{ }^{\circ} \mathrm{C}$, in Styrofoam trays with a capacity of 1.2 liters containing a homogeneous mixture of sand and soil (1:2). The substrate was kept with a moisture equivalent to $60 \%$ of the holding capacity. Four replicates of 50 seeds per lot were used, distributed in grooves 1 $\mathrm{cm}$ deep. The V1 step was considered, according to Fernandez et al. (1985), as an emerged seedling, which is characterized by the appearance of the curved hypocotyl at the soil surface, raising the cotyledons. The number of emerged plants were performed daily, determining the emergence speed index (ESI) through the equation suggested by Maguire (1962), IVE $=\mathrm{E} 1 / \mathrm{N} 1+\mathrm{E} 2 / \mathrm{N} 2+\ldots+$ $\mathrm{En} / \mathrm{Nn}$, in which E1, E2 and En: number of seeds emerged and computed in the first, second, until the last count; N1, $\mathrm{N} 2$ and Nn: number of days from sowing to first, second to the last count. Thus, higher index indicates greater vigor of the seed.

Fresh matter mass (FM) and dry (DM) of the aerial part of the seedlings: they were determined using normal seedlings that originated in greenhouse fifteen days after seedling emergence in Styrofoam trays. To determine the amount of FM, the fresh mass of the seedlings was obtained on a precision digital scale of $0.0001 \mathrm{~g}$, and the values were divided by the number of seedlings per replication, thus obtaining the average data in g.seedling ${ }^{-1}$. For the determination of DM, the seedlings were placed in paper bags and maintained in an incubator at $80^{\circ} \mathrm{C}$ until reaching constant mass, achieved within 24 hours. After this period, the mass was obtained in a precision scale of $0.0001 \mathrm{~g}$, 
thus achieving the average data in g.seedling $^{-1}$ (CastanedaSaucedo et al., 2009).

For the immersion test in the toxic solution, a completely randomized design was conducted in a $5 \times 5$ factorial scheme (5 lots x 5 times of immersion in toxic solution) with four replications. For other tests, the statistical design was completely randomized, with five treatments (seed lots) and four replications of 50 seeds each.

The data, when expressed in percentage, were previously transformed in arc sen $\sqrt{(x / 100)}$ and subjected to analysis of variance and regression. Means among treatments were compared by Tukey test at $5 \%$ probability. Pearson correlation was performed among treatments regarding the toxic solution and the other tests of vigor and germination. All analyzes were performed using the SAEG statistical program (SAEG, 2007).

\section{Results and Discussion}

The seed moisture content was $11.3 \%$, which, according to Marcos-Filho (2005) supports the storage of seeds, contributing to their longevity.

Significant difference between the means of the germination percentage of the lots was not detected (Table 1). It was also found that all lots showed germination values above the standard set by Brasil (2011) for the marketing of seeds of Phaseolus vulgaris, which is $80 \%$. Therefore, it was possible to use the five lots in order to differentiate them by the vigor test based on the principle of toxic solution, since, according to MarcosFilho (2005), comparisons of seed vigor of different lots become consistent only if their germination is similar to each other and above the standards established by the legislation in force.

Table 1. Means value of the germination test (GT), first count (FC), emergence speed index (ESI), emergence of seedlings (ES), fresh mass of the aerial part (FM) and dry mass of the aerial part (DM) of five lots of beans cultivar Carnaval MG.

\begin{tabular}{|c|c|c|c|c|c|c|}
\hline Lots & GT (\%) & FC (\%) & ESI & ES (\%) & FM (mg) & $\mathrm{DM}(\mathrm{mg})$ \\
\hline L1 & $92^{\mathrm{ns}}$ & $79^{\mathrm{ns}}$ & $6.82 \mathrm{~A}^{1}$ & $94^{\text {ns }}$ & $1.28^{\mathrm{ns}}$ & $0.20 \mathrm{~B}$ \\
\hline L2 & $86^{\mathrm{ns}}$ & $77^{\mathrm{ns}}$ & $6.08 \mathrm{AB}$ & $89^{\text {ns }}$ & $1.30^{\mathrm{ns}}$ & $0.50 \mathrm{~A}$ \\
\hline L3 & $82^{\mathrm{ns}}$ & $70^{\mathrm{ns}}$ & $5.15 \mathrm{~B}$ & $80^{\text {ns }}$ & $1.46^{\mathrm{ns}}$ & $0.28 \mathrm{~B}$ \\
\hline L4 & $88^{\text {ns }}$ & $79^{\text {ns }}$ & $6.89 \mathrm{~A}$ & $94^{\mathrm{ns}}$ & $1.32^{\mathrm{ns}}$ & $0.24 \mathrm{~B}$ \\
\hline L5 & $83^{\text {ns }}$ & $72^{\text {ns }}$ & $6.71 \mathrm{~A}$ & $93^{\text {ns }}$ & $1.42^{\mathrm{ns}}$ & $0.24 \mathrm{~B}$ \\
\hline CV (\%) & 7.32 & 10.44 & 8.18 & 9.94 & 23.67 & 17.72 \\
\hline
\end{tabular}

${ }^{1}$ Means followed by the same letter in the column do not differ among themselves by the Tukey test at $5 \%$ probability. ${ }^{\text {ns }}$ non-significant by the F Test.

As for the means related to seed vigor after immersion in toxic solution, the interaction effect among the factors analyzed was found (Table 2). It is noted, regardless of the time applied, that it was possible to differentiate between existing lots of beans, which demonstrates the effectiveness of the test, confirming the results found by
Boaro et al. (1984) who, after comparing some vigor tests, concluded that the immersion test in toxic solution proved to be the most effective to evaluate the physiological quality of bean seeds. Nonetheless, Marcos-Filho et al. (1987) report the toxic solution test as drastic for dicotyledonous seeds.

Table 2. Germination (\%) of bean seed lots, cultivar Carnaval MG, immersed for different times in toxic solution.

\begin{tabular}{cccccc}
\hline \multirow{2}{*}{ Lots } & \multicolumn{5}{c}{ Immersion time to toxic solution (minutes) } \\
\cline { 2 - 6 } & 15 & 30 & 45 & 60 & 75 \\
\hline L1 & $98 \mathrm{Aa}^{1}$ & $91 \mathrm{Aab}$ & $98 \mathrm{Aa}$ & $\mathrm{ABb}$ & $92 \mathrm{Aab}$ \\
$\mathrm{L} 2$ & $86 \mathrm{Ba}$ & $87 \mathrm{ABa}$ & $87 \mathrm{Ba}$ & $72 \mathrm{Bab}$ & $55 \mathrm{Bb}$ \\
$\mathrm{L} 3$ & $84 \mathrm{Ba}$ & $74 \mathrm{Bab}$ & $83 \mathrm{Ba}$ & $90 \mathrm{Aa}$ & $55 \mathrm{Bb}$ \\
$\mathrm{L} 4$ & $87 \mathrm{Ba}$ & $92 \mathrm{Aa}$ & $90 \mathrm{ABa}$ & $82 \mathrm{ABa}$ & $83 \mathrm{Aa}$ \\
L5 & $84 \mathrm{Ba}$ & $88 \mathrm{ABa}$ & $87 \mathrm{Ba}$ & 80 &
\end{tabular}

${ }^{1}$ Means followed by the same lowercase letter in the line and uppercase in the column do not differ by the Tukey test at $5 \%$ probability.

With the time of 15 minutes of immersion in the toxic solution, the superiority of lot L1 was verified in relation to the others (Table 2). In the time of 30 minutes, this lot did not differ statistically from lots L2, L4 and L5. In this time, it was possible to distinguish lots L1 and L4 from lot L3, whose vigor was lower. In the time of 45 minutes it was possible to 
differentiate lot L1 from lots L2, L3 and L5, and lot L4 did not differentiate from any other lot, showing an average vigor. In the time of 60 minutes, only lots L3 and L4 showed a significant difference from each other, and the last was the one with higher vigor (Table 2). In the time of 75 minutes, lots L1, L4 and L5 showed higher vigor than the other lots and did not differ from each other. Thus, in the analysis of seed vigor by immersion in toxic solution test, it was observed that, in general, lot L1 showed more vigor than the other lots and lot L3, lower vigor.

It was not possible to differentiate the vigor of lots of beans by the first count seedling emergence and fresh matter of the aerial part (FM) (Table 1). The results of the first count and of FM did not detect differences in vigor between lots, which corroborates Bhering et al. (2003), according to whom these tests show low sensitivity. According to Delouche and Baskin (1973) the reduction of the germination rate is not among the first events of the deterioration process of the seeds. The seedling emergence test, on the other hand, is regarded as a test of greater sensitivity than the tests in laboratory, capable of detecting small differences in vigor. Nevertheless, the application of this test was unable to distinguish the vigor of the lots, and it is possible, however, to differentiate them by the toxic solution test (Table 2).

Nevertheless, still observing the data in Table 1, it was possible to distinguish the lots by the emergence speed index (ESI) and the dry matter of the aerial part (DM). The differentiation of the vigor among lots by ESI was analogous to that indicated by the toxic solution test with immersion time of 75 minutes where lots L1, L4 and L5 showed better vigor than lot $\mathrm{L} 3$.

The results of the ESI positively correlated at 5\% significance to the outcome of the immersion in toxic solution for 75 minutes (Table 3). This is consistent with the results observed by Tekrony and Egli (1977) working with soybeans and by Guiscem et al. (2001) with sweet corn seeds. On the other hand, the results of the DM negatively correlated at $1 \%$ significance to the obtained by immersion test in toxic solution for 75 minutes.

Table 3. Correlation coeficients among the germination tests (GT), first count (FC), emergence speed index (ESI), seedling emergence (SE), fresh mass of the aerial part (FM) and dry mass of the aerial part (DM) and the immersion in toxic solution test of bean seeds, cultivar Carnaval MG, at different DS times.

\begin{tabular}{|c|c|c|c|c|c|}
\hline \multirow{2}{*}{ Parameters } & \multicolumn{5}{|c|}{ Immersion time in toxic solution (minutes) } \\
\hline & 15 & 30 & 45 & 60 & 75 \\
\hline GT & $0.2039^{\mathrm{ns}}$ & $0.3736^{\mathrm{ns}}$ & $0.1110^{\mathrm{ns}}$ & $0.7379 * *$ & $0.2569^{\mathrm{ns}}$ \\
\hline $\mathrm{FC}$ & $0.1372^{\mathrm{ns}}$ & $0.3494^{\mathrm{ns}}$ & $0.2081^{\mathrm{ns}}$ & $0.6704 * *$ & $0.3194^{\mathrm{ns}}$ \\
\hline ESI & $0.2727^{\mathrm{ns}}$ & $0.6549 * *$ & $0.3242^{\mathrm{ns}}$ & $0.4929 * *$ & $0.6040^{*}$ \\
\hline SE & $0.3696^{\mathrm{ns}}$ & $0.4425 *$ & $0.4123 *$ & $0.3521^{\mathrm{ns}}$ & $0.4048 * *$ \\
\hline FM & $-0.1004^{\mathrm{ns}}$ & $-0.1498^{\mathrm{ns}}$ & $0.1159^{\text {ns }}$ & $-0.1171^{\mathrm{ns}}$ & $0.0381^{\mathrm{ns}}$ \\
\hline DM & $-0.3609^{\mathrm{ns}}$ & $-0.2096^{\mathrm{ns}}$ & $0.2554^{\mathrm{ns}}$ & $-0.1368^{\mathrm{ns}}$ & $-0.6179 * *$ \\
\hline
\end{tabular}

**; * significant correlation at $1 \%$ and $5 \%$, respectively; ${ }^{\mathrm{ns}}$ non-significant correlation.

In the analysis of the correlation coefficients obtained between the tests performed (Table 3), it was possible to determine a positive correlation among the immersion period of 60 minutes, the results of the germination test and the first count. These results partially agree with the observations from Boaro et al. (1984) who, when assessing the vigor of beans seeds by the toxic solution test, also noticed a significant correlation with the germination test and the first count; however, they tested only the immersion time of 30 minutes. With this result, it is noted that the toxic solution test with immersion of 60 minutes can show satisfactory results if used for research in laboratory.

A positive correlation was also observed between ESI and the immersion period in the toxic solution for 30 minutes (Table 3). Thus, the immersion time of 30 minutes can be used as an indirect assessment of the behavior of bean seeds in the field, making for more efficient assessments in the laboratory, by the ability to predict the behavior of the seed in the field. This was also observed by other authors correlating the results of the immersion test in toxic solution with field emergence to sorghum seeds (Abdulahi and Vanderlip, 1972; Yayock et al., 1975; Ahmed, 1977; Petrini et al., 1988).

Comparing the time of toxic solution immersion between 30 and 75 minutes, the correlation was significant in the period of 30 minutes, resulting in a more adequate prediction than 75 minutes, besides being faster. The presence of a non significant correlation among the results highlights the need to evaluate the physiological quality in smaller immersion time in toxic solution.

As for the regression analysis, the results of lots L1, L4 and L5 did not fit satisfactorily in the simple regression models 
$(y=\bar{x})$. Figure 1 shows the regression curves to represent the viability of bean seeds of lots L2 and L3 after immersion in toxic solution. It was found that the germination of the bean seeds declined over the time of immersion in toxic solution, and this reduction was greater in the period of 75 minutes. There was a quadratic behavior for lot $\mathrm{L} 2(\mathrm{Y}=82.875+$ $0.62631 \mathrm{x}-0.0125794 \mathrm{x}^{2}$ ), by which $91 \%$ of germination were obtained with the optimal immersion time of 25 minutes. For lot L3 $\left(\mathrm{Y}=80.8063+0.251071 \mathrm{x}-0.0075 \mathrm{x}^{2}\right)$, the maximum germination after immersion in toxic solution was $83 \%$, with the optimal time of 17 minutes.

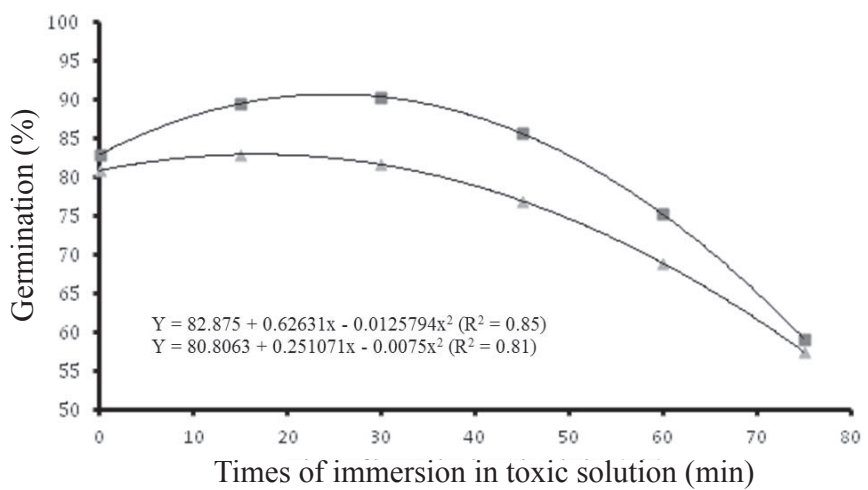

= Lot $2 \quad$ Lot 3

Figure 1. Germination of bean seeds of cultivar Carnaval MG after different immersion periods in toxic solution.

\section{Conclusions}

The immersion of the seeds in toxic solution of ammonium chloride $1 \%$ for 30 minutes is effective to detect vigor differences between lots of bean seeds.

\section{Acknowledgments}

To CAPES and CNPq, for granting the scholarships.

\section{References}

ABDULAHI, A; VANDERLIP, R. L. Relationships of vigor tests and seed source and size to sorghum seedling establishment. Agronomy Journal, v.64, n.2, p.143-144, 1972. https://www.agronomy.org/publications/aj/ abstracts/64/2/aj0640020143

AHMED, H. D. Evaluating differences in vigor amongst sorghum seed lots by various test methods. Seed Research, v.5, p.152-157, 1977. http://www. sroseed.com/resources/articles.html

ANDRADE, R. V.; AZEVEDO, J. T.; BORBA, C. S.; OLIVEIRA, A. C. Teste de vigor em sementes de sorgo para predizer o armazenamento. Revista Brasileira de Sementes, v.15, n.2, p.171-175, 1993. http://www.abrates.org. br/revista/artigos/1993/v15n2/artigo05.pdf
BHERING, M. C; DIAS, D. C. F. S.; BARROS, D. I.; DIAS, L. A. S.; TOKUHISA, D. Avaliação do vigor de sementes de melancia (Citrullus lunatus Scharad.) pelo teste de envelhecimento acelerado. Revista Brasileira de Sementes, v.25, n.2, p.1-6, 2003. http://www.scielo.br/pdf/rbs/v25n2/19642.pdf

BOARO, C. S. F.; CARVALHO, V. L. M.; BICUDO, L. R. F.; NAKAGAWA, J. Estudo de testes em laboratório para avaliar a qualidade fisiológica de sementes de feijão. Revista Brasileira de Sementes, v. 6, n. 2, p. 77-86, 1984. http://www.abrates.org.br/revista/artigos/1984/v6n2/artigo08.pdf

BRASIL. Ministério da Agricultura, Pecuária e Abastecimento. Regras para análise de sementes. Ministério da Agricultura, Pecuária e Abastecimento. Secretaria de Defesa Agropecuária. Brasília: MAPA/ACS, 2009. 395 p. http://www.agricultura.gov.br/arq_editor/file/laborat $\%$ c3\%b3rio/sementes/ regras $\% 20$ para $\% 20$ analise $\% 20 \mathrm{de} \% 20$ sementes.pdf

BRASIL. Portaria Secretaria de Defesa Agropecuária. Padrões de identidade e qualidade para a produção e a comercialização de sementes de espécies olerícolas, condimentares, medicinais e aromáticas. Diário Oficial da União, Brasília, $N^{\circ} 51$ de 2 de março de 2011. Seção I.

BORGES, J. W. M.; FRAGA, A. C.; SILVEIRA, J. F.; AQUINO, L. H. Efeitos de misturas de sementes de milho sobre a germinação e vigor. Revista Brasileira de Sementes, v.9, n.2, p.45-54, 1987. http://www.abrates.org.br/ revista/artigos/1987/v9n2/artigo04.pdf

CARDOSO SOBRINHO, J.; SILVA, J. N.; CORRÊA, P. C.; DIAS, D. C. F. S. Qualidade de sementes de sorgo (Sorghum bicolor L.) conforme a sua localização no secador de leito fixo com distribuição radial de ar. Revista Brasileira de Engenharia Agrícola e Ambiental, v.2, n.1, p.89-93, 1998. http://www.agriambi.com.br/revista/v2n1/089.pdf

CASTANEDA-SAUCEDO, M. C.; LOPEZ-CASTANEDA, C.; COLINASDE-LEON, M. T. B. Rendimiento y calidad de la semilla de cebada y trigo en campo e invernadero. INCI, v.34, n.4, p.286-292, 2009. http://www. interciencia.org/v34_04/index.html

DELOUCHE, J. C.; BASKIN, C. C. Accelerated aging techniques for predicting the relative storability of seed lots. Seed Science and Technology, v.1, n.2, p.427-452, 1973. http://www.seedtest.org/en/seed-science-andtechnology-_content---1--1084.html

FERNÁNDEZ, F.; GEPTS, P.; LÓPEZ, M. Etapas de desarrollo en la planta de frijol. In: LÓPEZ, M.; FERNÁNDEZ, F.; VAN SCHOONHOVEN, A. (eds.). Frijol: investigación y producción. Cali, PNUD, CIAT, p.61-78, 1985. http://orton.catie.ac.cr/cgi-bin/wxis.exe/?IsisScript=IICACR.xis\&metho$\mathrm{d}=$ post \& formato $=2 \&$ cantidad $=1$ \&expresion $=\mathrm{mfn}=026797$

GUISCEM, J. M.; ZUCARELI, C.; NAKAGAWA, J.; ZANOTTO, M. D. Correlação de testes de vigor com emergência no campo e germinação em laboratório em sementes de milho doce BR 400 (gene bt). Informativo ABRATES, v.11, n.2, p. 107, 2001.

KHAJEH-HOSSEINI, M.; REZAZADEH, M. The electrical conductivity of soak-water of chickpea seeds provides a quick test indicative of field emergence. Seed Science and Technology, v.39, p.692-696, 2011. http://www. ingentaconnect.com/content/ista/sst/2011/00000039/00000003/art00018

KIKUTI, A. L. P.; MARCOS-FILHO, J. Testes de vigor em sementes de alface. Horticultura Brasileira, v.30, p.44-50, 2012. http://www.scielo.br/ $\mathrm{pdf} / \mathrm{hb} / \mathrm{v} 30 \mathrm{n} 1 / \mathrm{v} 30 \mathrm{n} 1 \mathrm{a} 08 . \mathrm{pdf}$

MAGUIRE, J. D. Speed of germination and seedling emergence and vigor. Crop Science, v. 2, n. 2, p. 176-177.

MARCOS-FILHO, J.; CÍCERO, S. M.; SILVA, W. R. Avaliação da qualidade de sementes. Piracicaba: FEALQ, 1987. 230p. 
MARCOS-FILHO, J. Fisiologia de sementes de plantas cultivadas. Piracicaba: FEALQ, 2005. 495p.

PETRINI, J. A.; FERNANDEZ, D.; ZONTA, E. P. Testes de vigor para predizer a emergência de sorgo. Pesquisa Agropecuária Brasileira, v.23, n.6, p.593-598, 1988. http://seer.sct.embrapa.br/index.php/pab/issue/archive?issuesPage=11

RIX, K. D.; GRACIE, A. J.; POTTS, B. M.; BROWN, P. H.; SPURR, C. J.; GORE, P. L. Germination response of Eucalyptus globulus seeds exposed to low and high temperature stress. Seed Science and Technology, v.39, p.686691, 2011. http://www.ingentaconnect.com/search/article?option1=tka\&value $1=$ germination + response + of + eucalyptus + globulus + seeds + exposed +to + low + and + high + temperature+stress.\&pagesize $=10$ \&index $=1$

SAEG - Sistema para análises estatísticas, versão 9.1. Viçosa: Fundação Arthur Bernardes, UFV. CD ROM, 2007.

SILVA, J. N. S.; CARDOSO SOBRINHO, J.; CARVALHO, J. A.; DIAS, D. C. F. S.; REIS, F. P. Qualidade fisiológica de sementes de sorgo coletadas em diferentes pontos de um secador. Revista Brasileira de Engenharia Agrícola e Ambiental, v.5, n.3, p.487-491, 2001. http://www.scielo.br/pdf/rbeaa/v5n3/ v5n3a20.pdf

SOARES, M. M.; CONCEIÇÃO, P. M.; DIAS, D. C. F. S.; ALVARENGA, E. M. Testes para avaliação do vigor de sementes de sorgo com ênfase à condutividade elétrica. Ciência e Agrotecnologia, v.34, n.2, p.391-397, 2010. http://www.editora.ufla.br/site/ adm/upload/revista/34-2-2010 17.pdf

TEKRONY, D. M.; EGLI, D. B. Relationship between laboratory indices of soybean seed vigor and field emergence. Crop Science, v.17, n.4, p.573-577, 1977. https://www.crops.org/publications/cs/

YAYOCK, J.; HALIN, J.; VANDERLIP, R. L. Temperature time and $\left(\mathrm{NH}_{4}\right) \mathrm{Cl}$ concentration in vigor testing of sorghum seed. Agronomy Journal, v.67, n.2, p.241-242, 1975. https://www.agronomy.org/publications/aj/ 